\title{
PEMBENTUKAN VERBA ERGATIF DALAM BAHASA HOKKIEN: KAJIAN MORFOSINTAKSIS
}

\author{
Sherly Novita ${ }^{1}$, Mulyadi ${ }^{2}$ \\ email: sherly.novita.1991@gmail.com,mulyadi.usu@gmail.com \\ Program Magister Linguistik, Universitas Sumatera Utara
}

\begin{abstract}
Abstrak-Artikel ini membahas tentang pembentukan verba ergatif dalam bahasa Hokkien. Suatu bahasa dikatakan bertipe ergatif apabila pasien (P) dari verba transitif diperlakukan sama atau koreferensial dengan subjek (S) pada klausa intransitif dan berbeda dengan agen (A) dari verba transitif. Verba ergatif memperlakukan P sama dengan S. Biasanya sama-sama tidak bermarkah. Kalimat yang bertipe akusatif adalah kalimat yang memiliki sistem dimana A sama dengan $\mathrm{S}$ dan perlakuan yang berbeda dengan $\mathrm{P}$. Sedangkan kalimat yang bertipe aktif adalah tipe kalimat yang menunjukkan bahwa ada sekelompok $\mathrm{S}$ yang berperilaku sama dengan $\mathrm{P}$ dan sekelompok $\mathrm{S}$ yang berperilaku sama dengan A dalam satu bahasa.
\end{abstract}

Dalam bahasa Hokkien, sebagian besar kata verba dapat digunakan secara intransitif, tetapi biasanya itu tidak mengubah peran subjek. Contohnya, "I crak mien pau" (Dia makan roti) (transitif) dan "I crak" (Dia makan) (intransitif), dimana satu-satunya perbedaan adalah bahwa yang terakhir tidak menentukan apa yang dimakan. Sebaliknya, dengan verba ergatif, peran subjek berubah; seperti "Jack $p^{\mathrm{h}}$ on $\mathrm{p}^{\mathrm{h}}$ ua pua" (Jack memecahkan piring) (transitif) dan "pua p ua" (piring pecah) (intransitif).

Kata Kunci: Hokkien, verba ergatif, transitif, intransitif subjek, agen, pasien.

\begin{abstract}
This article is discussing about the formation of ergative verb in Hokkien. A language can be called as ergative if the patient $(\mathrm{P})$ of the transitive verb is treated equally or conferential with the subject $(\mathrm{S})$ in the intransitive clause and is different from the agent (A) of the transitive verb. Ergative verb treats $\mathrm{P}$ equally with $\mathrm{S}$. It is usually no indication for both. Accusative sentence is a sentence which has a system where $\mathrm{A}$ is equal with $\mathrm{S}$ and is different with $\mathrm{P}$. However, active sentence is a type of sentence which shows a group of $\mathrm{S}$ which are acting the same with $\mathrm{P}$ and a group of $\mathrm{S}$ which are acting the same with $\mathrm{A}$ in a language.
\end{abstract}

In Hokkien, most verbs can be used intransitively, but usually this does not change the subject's role. For example, "I crak mien pau" (He eats bread) (transitive) and "I crak" (He eats) (intransitive), where the only difference is that the latter does not determine what is eaten. By contrast, with ergative verbs, the subject's role changes; such as "Jack $\mathrm{p}^{\mathrm{h}}$ on $\mathrm{p}^{\mathrm{h}}$ ua pua" (Jack broke the plate) (transitive) dan "pua $\mathrm{p}^{\mathrm{h}}$ ua" (the broken plate) (intransitive).

Keywords - Hokkien, verb, ergative, transitive, intransitive, subject, agent, patient. 


\section{PENDAHULUAN}

Bahasa Hokkien atau Medan Hokkien adalah suatu variasi dialek Hokkien lokal yang digunakan di kota Medan, Sumatera Utara, Indonesia. Semua warga Tionghoa di Medan menggunakan bahasa Hokkien ketika berkomunikasi dengan sanak keluarga, teman, serta sesama warga Tionghoa, walaupun mereka berasal dari berbagai suku dengan bahasa suku yang lain, contohnya: suku Hokkien, Teo Chew, Kong Hu, Hakka, Khek, Hai Nan, Hai Lok Hong, Heng Hwa, dan berbagai suku yang lain. Suku yang berbeda memiliki makna bahwa masingmasing individu menguasai bahasa sukunya yang diturunkan oleh kedua orang tuanya. Sedangkan untuk kota Medan, bahasa yang dipakai untuk berkomunikasi di kalangan semua warga Tionghoa yang berbeda suku ini adalah bahasa Hokkien. Berdasarkan hal ini, penulis mengidentifikasi bahasa Hokkien, untuk melihat dan mengetahui secara mendalam bagaimana sistem bahasa ini pada masyarakat penuturnya.

Setiap bahasa tentunya memiliki verba, baik verba transitif maupun verba intransitif. Verba transitif merupakan verba yang memerlukan objek dalam pembentukannya di dalam kalimat, dan dapat diubah kedalam bentuk pasif. Sedangkan verba intransitif merupakan verba yang tidak memerlukan objek dalam pembentukannya di dalam kalimat dan tidak dapat diubah kedalam bentuk pasif karena tidak adanya kenaikan objek aktif menjadi subjek pasif. Ergatif menurut Wikipedia adalah verba yang dapat digunakan dalam bentuk transitif dan intransitif dengan makna yang sama dimana objek transitif sama dengan subjek intransitif.

Menurut Dale (2016), pola kasus atau perjanjian yang ergatif berisi formulir khusus untuk menandai atau mengindeks transitif subjek (ergatif), sering bertentangan dengan bentuk yang digunakan untuk objek dan subjek intransitif (absolutif). Salah satu pertanyaan tertua dan terpenting yang diangkat oleh sistem semacam itu menyangkut hubungan antara morfologi dan sintaksis. Kita tahu bahwa dalam bahasa nominatif-akusatif, kasusnya morfologi nominal sering berkorelasi secara sentral dengan perilaku sintaksisnya. Nomina-argumentif kontras dengan yang akusatif baik dalam hal dan atau morfologi perjanjian dan dalam properti sintaksis seperti kerentanan untuk meningkatkan atau kemampuan untuk menolak ko-argumen fleksibel. Dalam bahasa Hokkien, contohnya, sebagian besar kata verba dapat digunakan secara intransitif, tetapi biasanya ini tidak mengubah peran subjek.

\section{METODE PENELITIAN}

Penelitian ini adalah penelitian morfosintaksis bahasa Hokkien yang termasuk dalam penelitian kualitatif. Data penelitian ini adalah kalimat-kalimat bahasa Hokkien. Pengumpulan data dalam tulisan ini dilakukan dengan teknis cakap semuka yang dikemukakan oleh Sudaryanto (2015) dengan cara memancing dan mengarahkan informan untuk memperoleh data selengkap-lengkapnya sebanyak tipe data yang dikehendaki. Dalam hal ini, baik peneliti maupun informan dipancing datanya secara bersama-sama sebagai satu kesatuan yang dapat dipandang sebagai alatnya. Informan yang dipilih juga telah dipertimbangkan yang sadar akan peranannya sebagai nara sumber yang pada hakikatnya alat pemeroleh data itu.

\section{HASIL PENELITIAN DAN PEMBAHASAN}

Penganalisisan data dilakukan berdasarkan bentuk, proses pembentukannya, perilaku atau fungsi yang didudukinya. Analisis mengenai perilaku atau fungsi yang diduduki suatu jenis kata dilakukan dengan cara menempatkannya pada suatu fungtor dalam konstruksi kalimat. Tulisan ini menggunakan Teori Tipologi Kausatif yang dikemukakan oleh Comrie (1989) dan Teori Tata Bahasa Relasional 
yang dikembangkan oleh Perlmutter dan Postal (1984).

\section{Landasan Teori}

Teori morfosintaksis digunakan untuk menganalisis data penelitian ini. Teori ini berasal dari dua bidang kajian yaitu morfologi dan sintaksis. Morfologi membahas tentang pembentukan struktur kata, sedangkan sintaksis membahas tentang hubungan antar kata dan tuturan yang meliputi satuan gramatikal seperti frasa, klausa, dan kalimat. Oleh karena itu, kajian teori tentang pembentukan verba ergatif bahasa Hokkien ini diarahkan pada sifat-prilaku tipologis tataran morfosintaksis. Sebutan bahasa akusatif, ergatif, atau bahasa aktif dikaitkan dengan tipologi gramatikal dan sistem aliansi gramatikal pada tataran morfosintaksis. Dalam tipologi linguistik, sebutan gramatikal lazim dirujuk sebagai tataran morfosintaksis. Sehubungan dengan itu, pembahasan kalimat dalam penelitian ini didasarkan pada data kebahasaan secara morfosintaksis dengan penekanan pada aspek sintaksisnya. (Comrie, 1989 dan Artawa, 2000 dan 2005)

\section{Tinjauan Pustaka}

Terdapat empat tulisan yang digunakan sebagai acuan atau tinjauan pustaka dalam penelitian ini, yaitu jurnal yang dibuat oleh Zaenal Arifin (2006) yang berjudul "Konstruksi Ergatif Baru dalam Bahasa Nusantara" yang juga membahas tentang verba ergatif bahasabahasa nusantara yang secara morfologis memiliki ciri ergatif. Bahasa-bahasa di dunia dapat memiliki ciri sintaks akusatif dan ergatif. Ciri sintaks akusatif artinya dengan memperlakukan subjek intransitif (S) sama dengan subjek transitif (A) dengan cara yang sama (tidak bermarkah), sedangkan objek transitif (O) diperlakukan secara berbeda (bermarkah). Sedangkan untuk ergatif, yaitu dengan memperlakukan $\mathrm{S}$ dan $\mathrm{O}$ dengan cara yang sama (tidak bermarkah) dan A diperlakukan dengan cara yang berbeda (bermarkah). Lalu, keergatifan juga dapat terjadi pada bahasa-bahasa yang memiliki konstruksi yang S, O, dan A-nya semua bermarkah, tetapi $\mathrm{S}$ dan O-nya memiliki markah yang sama, sedangkan A-nya memiliki markah yang berbeda.

Tulisan lain terkait verba ergatif ditemukan dalam artikel "Analisis Kalimat Ergatif dalam Tajuk Berita Detik.com" karya Handoko (2015). Dalam artikel ini, disimpulkan bahwa kalimat ergatif dapat ditandai secara morfologis, leksikal, dan sintaksis. Penanda morfologis dapat berupa penambahan afiks ke-an atau prefiks ter-. Penanda leksikal dapat berupa penggunaan verba ergatif. Namun, dengan menggunakan teori penguasaan dan pengikatan (government and binding) tampak bahwa ergativitas bukanlah penambahan afiks atau penggunaan leksikal tertentu, tapi adalah perlakuan frasa nomina $S$ sama dengan frasa nomina $\mathrm{O}$ dan berbeda dengan frasa nomina $\mathrm{A}$ dengan pivot S/O. Penggunaan bentuk ergatif dalam tajuk berita merupakan strategi pembuat berita untuk menarik perhatian pembaca dengan mengedepankan korban sebagai inti kalimat.

\section{Dalam tulisan lain yang berjudul} "Fenomena Tipologi Gramatikal Bahasa MinangKabau: Akusatif, Ergatif, atau Campur" oleh Jufrizal (2008). Dalam artikel ini, dijelaskan bahwa walapun bahasa MinangKabau telah dianggap dan dilaporkan secara gramatikal adalah bahasa akusatif pada tataran sintaksis, namun bahasa ini juga beralasan untuk dikelompokkan sebagai bahasa campur atau netral.

Artikel berikut yang terkait dengan verba ergatif yakni "Perilaku dan Makna Verba dalam Bahasa Madura" oleh Akhmad Sofyan (2012). Berdasarkan maknanya, verba dalam bahasa Madura terdiri atas verba kausatif, benefaktif, resiprokal, refleksif, lokatif, repetitif, dan imperatif. Data yang dianalisis dalam bahasa Madura diperoleh melalui wawancara dengan menggunakan kuesioner terbuka (metode deskriptif-kualitatif).

\section{Peran Semantis}


Peran semantis yang dimaksud adalah peran semantis yang ada hubungannya atau dalam tipologi bahasa dan aliansi gramatikal. Pengkajian aliansi gramatikal pada dasarnya didasari dan dicermati melalui kajian tipologi bahasa yang bersangkutan. Dalam hal ini, semua bahasa memiliki struktur yang verbanya berbentuk transitif dan intransitif. Verba intransitif memerlukan hanya satu argumen saja, sedangkan verba transitif menghendaki dua argumen atau lebih. Perhatikan istilah-istilah argumen yang dikehendaki oleh verba intransitif dan transitif. Istilah-istilah yang dipakai dikutip dari Comrie (1989), sebagai berikut:

S $($ Subjek $)=$ satu-satunya argumen dalam kalimat intransitif transitif

A $($ Agen $)=$ argumen agen dalam kalimat

$\mathrm{P}$ (Pasien) $=$ argumen pasien dalam kalimat transitif

Lebih lanjut dikatakan bahwa $\mathrm{S}$ merupakan patokan dalam menentukan tipologi bahasa yang dapat dilakukan secara morfologis dan sintaksis. Yang dimaksudkan di sini adalah bahwa $\mathrm{A}$ atau $\mathrm{P}$ bisa diperlakukan dengan cara yang sama dengan S. Perilaku sintaksis A atau P dipergunakan sebagai alat ukur untuk menentukan tipe suatu bahasa. Sehingga dengan demikian dapat dijelaskan bahwa: (a) apabila suatu bahasa memperlakukan $\mathrm{A}$ dan $\mathrm{S}$ dengan cara yang sama, maka bahasa tersebut digolongkan sebagai bahasa yang bertipe akusatif, (b) apabila $\mathrm{P}$ dan $\mathrm{S}$ diperlakukan dengan cara yang sama, maka bahasa tersebut digolongkan ke dalam bahasa yang ergatif. Penentuan penggolongan bahasa ini sangat bergantung dari perlakuan secara morfologis atau sintaksis. Sehingga dengan demikian, perbedaan perlakuan secara morfologis dan sintaksis suatu bahasa merupakan suatu hal yang sangat penting dalam tipologi bahasa.

\section{Tipologi Bahasa Subordinatif}

Dalam Bahasa Hokkien, sama halnya dengan bahasa lainnya, kalimat subordinatif dibangun dengan konjungsi yang dapat berbentuk antara lain: karena, sebab, jika, hanya jika, meskipun, walaupun, bahwa, agar, dan sebagainya. Berbicara mengenai tipologi Bahasa Hokkien ada baiknya terlebih dahulu melihat tipologi bahasa yang ada, yaitu: tipologi akusatif, aktif, pasif, ergatif dan antipasif. Dan yang akan dibahas lebih lanjut yaitu proses pembentukan verba ergatif dalam Bahasa Hokkien.

\subsection{Kalimat Ergatif}

Seperti dikatakan oleh Comrie (1988) dan Artawa (2004) bahwa kalimat yang bertipe ergatif bisa dilihat dari sudut pandang morfologi dan sintaksis, dan khusus penganalisisan kalimat ergatif secara diskursus bisa dilihat secara terperinci dalam Verhaar (2006). Kalimat ergatif secara morfologis adalah apabila komplemen subjek (S) verba intransitif dimarkahi dengan cara yang sama dengan pasien $(\mathrm{P})$ verba transitif, dan berbeda dari komplemen agen (A) verba transitif. Dan secara sintaksis dikatakan bahwa kalimat memiliki kaidah sintaksis yang memperlakukan S sama dengan $\mathrm{P}$, dan berbeda dari A. Perhatikan contoh kalimat subordinatif berikut ini:

1. John sək lien in gur lau sə me $\underline{\mathrm{i}} \mathrm{k}^{\mathrm{h}} \mathrm{i} \mathrm{p} \wedge \mathrm{n} \mathrm{e}$ $\mathrm{t}^{\mathrm{h}}$ au cey. (Hokkien)

John sedih karena guru memarahinya di depan kelas. (Bahasa Indonesia)

2. Mimi hau In gui p $\Lambda$ t to. (Hokkien)

Mimi menangis karena terjatuh. (Bahasa Indonesia)

3. Robin $\mathrm{p}^{\mathrm{h}} \Lambda \mathrm{k} \underline{\mathrm{kiam} h u} \mathrm{k}^{\mathrm{h}} \mathrm{i} \mathrm{p} \wedge \mathrm{j}$ pe $\underline{\mathrm{kau}}$ ta $\mathrm{k} \wedge \mathrm{p}$ e gia la be. (Hokkien)

Robin menjemur ikan asin di teras sampai kering dan siap untuk dijual. (Bahasa Indonesia)

Kalimat 1) sampai 3) merupakan kalimat yang bertipologi ergatif. Pada kalimat a) subjek 
'John' diperlakukan sama dengan pasien 'I'; pada kalimat 2) 'Mimi' dimarkahi sama dengan (dia) tetapi disimbolkan dengan $\theta$ atau dilesapkan; pada kalimat 3) pasien 'kıam hu' yang diperlakukan sama dengan subjek klausa subordinatif dilesapkan. Dilihat dari hubungan antara kedua klausa dalam kalimat koordinatif, dapat dijelaskan bahwa kalimat 1) dan 2) merupakan kalimat kompleks dengan konjungsi kausatif yang direalisasikan dengan 'In gur', dimana klausa inti 'John sək lien' merupakan efek dari klausa subordinatif yang dianggap sebagai penyebab kejadian. Oleh karena itu, hubungan kedua klausa itu menyebabkan munculnya kalimat yang kausatif. Sementara itu, dalam 3), klausa inti dihubungkan dengan konjungsi 'kau', sehingga hubungan ini menunjukkan bahwa terdapat kejadian yang diimplikasikan dari kejadian sebelumnya yang direalisasikan oleh klausa sebelumnya. Oleh karena itu, hubungan tipologi ergatif ini merupakan hubungan yang resultatif.

Sementara itu, kalimat yang bertipe akusatif adalah kalimat yang menggunakan simbol S, A, P (P yang menurut Dixon, 1979 termasuk di dalamnya adalah O). Artinya, dapat dianggap bahwa $\mathrm{P}$ itu mengandung peran semantis $\mathrm{O}$ di dalamnya. Dalam hal ini, akusatif terjadi apabila $\mathrm{S}$ diperlakukan sama dengan $\mathrm{A}$, tetapi berbeda dengan P. Perhatikan contoh kalimat subordinatif berikut ini:

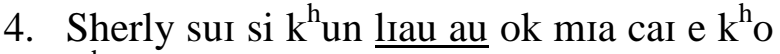
$\mathrm{t} \int^{\mathrm{h}}$ ek. (Hokkien)

Sherly langsung tidur setelah belajar untuk ulangan besok. (Bahasa Indonesia)

5. $\mathrm{T}^{\mathrm{h}} \mathrm{ia} \underline{\text { liau }}$ au bo ho siau sit, Jenny sit $\mathrm{k}^{\mathrm{h}} \mathrm{i}$. (Hokkien)

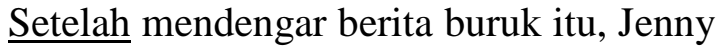
pingsan. (Bahasa Indonesia)

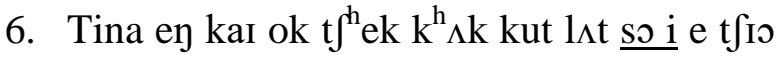
te it mia. (Hokkien)
Tina harus belajar dengan sungguhsungguh agar mendapat juara 1. (Bahasa Indonesia)

Kalimat 4) sampai 6) merupakan kalimat yang akusatif, dimana $S$ pada klausa inti diperlukan sama dengan A pada klausa subordinatif yang ditandai dengan $\varnothing$. Hubungan kedua klausa ini merupakan hubungan resultatif yang ditandai dengan konjungsi 'liau au' dan 's i'.

Dikatakan resultatif karena kejadian pada klausa inti merupakan implikasi dari klausa subordinatif.

\subsection{Kalimat Pasif dan Ergatif}

Kalimat ergatif telah dijelaskan di atas, namun sangat berbeda dengan kalimat pasif. Berikut disarikan beberapa parameter yang dapat membedakan tipologi kalimat ergatif dan kalimat pasif seperti yang diungkapkan oleh Artawa (2004):

a. pasif dan ergatif sama-sama melibatkan paling tidak properti $\mathrm{S}$ sama dengan $\mathrm{P}$ daripada A.

b. pasif dan ergatif berbeda dalam hal bahwa ergatif secara tipologis melibatkan integrasi yang lebih besar dari frasa agen ke dalam sintaksis klausa.

c. pasif dan ergatif berbeda dalam hal pemarkahan. Pasif itu merupakan kalimat yang berkonstruksi kalimat bermarkah, sedangkan konstruksi ergatif konstruksi tak bermarkah.

Perhatikan contoh kalimat subordinatif pasif berikut ini:

7. Sabrina ho ken $t \int^{\mathrm{h}} \Lambda \mathrm{t}$ liak e si kıa $\mathrm{k}^{\mathrm{h}} \mathrm{i}$ gu uan. (Hokkien)

Sabrina ditangkap polisi ketika berjalan di taman. (Bahasa Indonesia)

8. Hellen po ciok In guI sion sion hə t $\int^{\mathrm{h}}$ oy ti. (Hokkien) 
Hellen merasa terhina karena sering diejek teman-temannya. (Bahasa Indonesia)

9. Ha le nə kaI gi na tiok $\mathrm{k}^{\mathrm{h}} \curvearrowright$ tok kau par cə. (Hokkien)

Kedua anak itu disiksa sampai cacat. (Bahasa Indonesia)

Kalimat 7) sampai 9) merupakan kalimat pasif karena salah satu verba dimarkahi secara morfologis dengan penambahan prefik di- ' $h o$ ' dan 'trok'. Kalimat 7) merupakan kalimat yang resultatif sama dengan kalimat 9) yang merupakan resultatif juga. Pada 7) klausa inti merupakan implikasi dari klausa subordinatif, demikian juga dengan 9) dimana klausa subordinatif cacat 'par cə' merupakan implikasi dari klausa inti disiksa 'tıok $\mathrm{k}^{\mathrm{h}} \mathrm{\jmath}$ tok'. Sementara kalimat 8) merupakan hubungan yang kausatif dimana kejadian pada klausa inti merasa terhina 'po crok' merupakan efek dari atau disebabkan oleh kejadian klausa subordinatif, yaitu sering

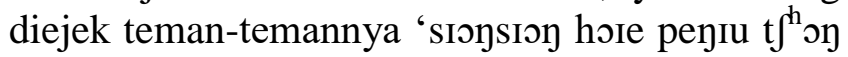
ti'.

\subsection{Kalimat Aktif dan Antipasif}

Kalimat aktif merupakan konstruksi dasar dari konstruksi akusatif, sementara kalimat antipasif merupakan konstruksi turunan dari kalimat ergatif. Dalam konstruksi antipasif diberlakukan bahwa pasien dalam konstruksi transitif dapat dilesapkan atau dihilangkan dari sebuah klausa. Dalam hal ini, aktif dan antipasif sama dalam hal bahwa agen memiliki properti subjek. Disamping itu, antipasif bisa digunakan untuk membuat kalimat yang ditransitif. Perhatikan contoh kalimat subordinatif berikut ini:

10. Orlando tek $\mathrm{k}^{\mathrm{h}} \Lambda \mathrm{k}$ na si Orlando e koI Blind Audition e Voice Kids Indonesia. (Hokkien)

Orlando yakin bahwa Orlando akan lulus dalam Blind Audition The Voice Kids Indonesia. (Bahasa Indonesia)
Kalimat 10) merupakan kalimat kompleks yang terdiri atas dua klausa, dimana klausa pertama merupakan antipasif (tidak bisa dipasifkan), dan klausa kedua merupakan klausa aktif yang statif. Dikatakan statif karena kejadian pada klausa inti 'yakin...' bukan merupakan implikasi dari klausa subordinatif yang ditandai dengan konjungsi bahwa 'na si'.

11. Ken $\mathrm{t}^{\mathrm{h}} \Lambda \mathrm{t}$ a bor $\mathrm{c} \Lambda \mathrm{\eta}$ be be pek hun e $1 \Lambda \eta$

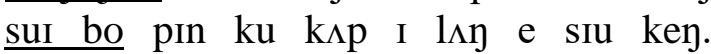
(Hokkien)

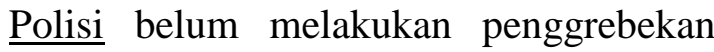
terhadap para pengedar narkoba meskipun telah mengantongi bukti dan tempat persembunyian mereka. (Bahasa Indonesia)

12. Ho liau tor $\mathrm{p}^{\mathrm{h}} \Lambda \mathrm{k} \mathrm{k}^{\mathrm{h}} \mathrm{Im}$ e $\mathrm{p} \Lambda \mathrm{n}$, Devi sur si tur t $\int^{h} u$. (Hokkien)

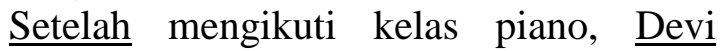
langsung pulang. (Bahasa Indonesia)

13. Ho liau $\mathrm{p}^{\mathrm{h}} \Lambda \mathrm{k}$ səy a ne ce bin mau, $\underline{\text { Robert }}$ en kai cek k ${ }^{\mathrm{h}}$ a lai siu. (Hokkien)

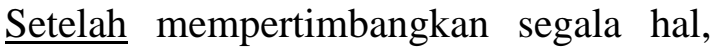
Robert harus mengalah. (Bahasa Indonesia)

14. ey kaI wu ka wu crak e $\mathrm{c} \Lambda \mathrm{p} \mathrm{mi}$ so i e en gıam si ıюn sın mıa go sıan sey. (Hokkien) Komposisi makanan pokok harus ada agar memenuhi syarat empat sehat lima sempurna. (Bahasa Indonesia)

15. Lau bu me wa e si wa crak sio ce səy suan a bo $\mathrm{t}^{\mathrm{h}} \mathrm{en}$ bo $\mathrm{t}^{\mathrm{h}} \mathrm{ej}$. (Hokkien)

Ibu memarahiku ketika aku makan banyak mangga muda tanpa henti. (Bahasa Indonesia)

16. Andri kra $\mathrm{k}^{\mathrm{h}} \mathrm{i} \mathrm{k}^{\mathrm{h}} \Lambda \mathrm{y}$ te e si ha le kau lai tur i. (Hokkien)

Andri berjalan ke lapangan ketika anjing mengejarnya. (Bahasa Indonesia) 
17. Ivan con re $\mathrm{t}^{\mathrm{h}}$ au $\mathrm{k}^{\mathrm{h}} \mathrm{i}$ prak e si re lau pe me i. (Hokkien)

Ivan membenturkan kepala ke tembok ketika ayah memarahinya. (Bahasa Indonesia)

Kejadian pada klausa inti pada kalimat 11) sampai dengan 17) merupakan implikasi dari klausa subordinatif yang dimarkahi oleh konjungsi 'meskipun' 'suı bo' pada kalimat 11), 'setelah' 'ho liau' pada kalimat 12) dan 13), 'agar' 'so i' pada kalimat 14), dan konjungsi 'ketika' 'e si' pada kalimat 15), 16) dan 17).

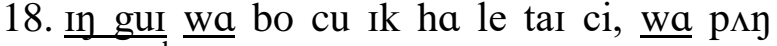
trau t $\mathrm{h}^{\mathrm{h}} \mathrm{u}$. (Hokkien)

Karena sayatidak menyadari masalah itu, saya meninggalkan rumah. (Bahasa Indonesia)

19. hiok pey sion $\mathrm{t} \int^{\mathrm{h}} \mathrm{e}$ sek, In guI tor $\mathrm{t} \int^{\mathrm{h}} \mathrm{e}$ hun Iok. (Hokkien)

Daun umumnya berwarna hijau, karena mengandung klorofil. (Bahasa Indonesia)

20. In guI Lina tur $\mathrm{t}^{\mathrm{h}} \mathrm{a}$ ma jit tau, $\underline{\mathrm{i}}$ bo tor khuI hoI. (Hokkien)

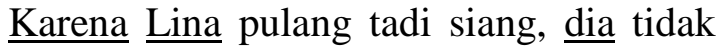
dapat menghadiri rapat. (Bahasa Indonesia)

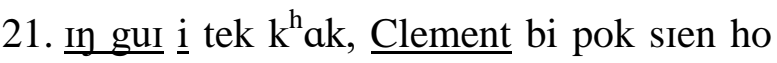
se. (Hokkien)

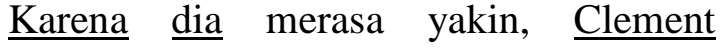
meramalkan sukses. (Bahasa Indonesia)

22. Irene cuan wa In guI wa $\mathrm{t}^{\mathrm{h}}$ au $\mathrm{k}^{\mathrm{h}} \mathrm{ua}$ i e $\mathrm{in}$. (Hokkien)

Irene mencubitku karena aku mencontek jawabannya. (Bahasa Indonesia)

Sementara itu, kalimat 18) sampai 22) merupakan kalimat yang kausatif. Dikatakan kausatif karena kejadian pada klausa inti merupakan efek atau dampak yang disebabkan oleh kejadian klausa subordinatif yang dimarkahi dengan konjungsi 'karena' 'In gur'.

\section{Perubahan Morfologis, Perubahan Argumen, dan Perilaku Koreferensial Kalimat Subordinatif}

Gabungan beberapa klausa yang berupa kalimat subordinatif, apabila dilihat dari segi struktur lahirnya, maka akan terjadi beberpa kemungkinan. Salah satunya adalah pelesapan. Hal ini terjadi karena perubahan morfologi yang terjadi terutama ditandai dengan pemarkahan. Perubahan morfologi pada verba itu biasanya dimarkahi dengan penambahan unit-unit sintaksis yang berupa sufiks, prefiks, ataupun konfiks. Oleh karena itu, perubahan tersebut akan berdampak pada pemaknaan verbanya. Dengan berubahnya makna karena perubahan morfologi itu, maka mempengaruhi pula argumen verba kalimatnya. Dengan kata lain, dapat dikatakan bahwa beban semantik Bahasa Hokkien mempengaruhi beban sintaksis gramatikal bahasa tersebut. Berdasarkan penjelasan ini, perilaku koreferensial argumen kalimat tersebut kemungkinan besar akan dilesapkan yang disebabkan oleh adanya perubahan tersebut. Lebih lanjut dapat dikatakan bahwa sistem koreferensial atau argumen yang sama dari klausa pembentuk kalimat subordinatif dengan jelas dapat dianalisis.

Sistem koreferensial mengacu pada perilaku argumen yang sama, baik secara eksplisit maupun secara implisit. Secara eksplisit berarti bahwa kekoreferensialan argumen dari salah satu klausa kalimat kompleks dimunculkan dalam kalimat tersebut. Dengan kata lain, tidak terjadi pelesapan argumen pada klausa kalimat kompleks tersebut. Sebaliknya, secara implisit artinya bahwa kekoreferensialan argumen dapat dimengerti dengan melakukan uji struktur batin kalimatnya. Dengan kata lain, dapat dikatakan bahwa terjadi pelesapan argumen pada salah satu klausa klaimat kompleks tersebut. secara morfologis.

Keberadaan bentuk morfologis verba atau predikat klausa inti ada yang mengalami perubahan dan ada yang tidak. Verba yang tidak 
mengalami perubahan yang dimaksud adalah verba dasar yang memiliki makna tertentu, sementara verba yang bermarkah secara morfologis mengalami perubahan. Beban semantik yang dilihat dari makna verba tersebut menentukan jumlah argumen inti setiap klausa, baik klausa inti maupun klausa subordinatifnya. Keberadaan sintaksis klausa inti memiliki hubungan atau relasi dengan klausa subordinatif yang didasarkan sepenuhnya dari makna verba dan keberadaan konjungsi. Kemudian, hubungan antara kedua klausa itu bisa dilihat secara anafora dan katafora. Yang dimaksud dengan anafora adalah keberadaan argumen dengan peran semantisnya berhubungan lurus ke depan ke klausa berikutnya yang ditandai pula dengan penggunaan atau kemunculan argumennya. Perhatikan beberapa contoh kalimat subordinatif bahasa Indonesia berikut ini yang dikemas dalam bentuk gabungan dua klausa.

\section{Pola Gabungan Klausa Intransitif dan Intransitif}

Seperti diketahui bahwa argumen yang muncul pada klausa intransitif adalah subjek (S) saja. Oleh karena itu, gabungan klausa intransitif dengan klausa intransitif akan memunculkan 2 argumen subjek yang sama. Sehingga dengan demikian, kekoreferensialan argumen dapat dikatakan bahwa $S=S$. Artinya subjek dari klausa intransitif pertama sama dengan atau koreferensial dengan subjek klausa kedua. Dalam hal ini hanya ada satu kemungkinan koreferensial. Perhatikan contoh kalimat subordinatif berikut ini:

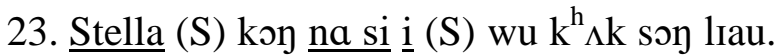
(Hokkien)

Stella (S) berkata bahwa dia (S) merasa lebih baik. (Bahasa Indonesia)

24. Franda (S) tur $t \int^{h} u$ In gui $\underline{i}$ (S) $p^{\text {h } u a ~ p e . ~}$ (Hokkien)

Franda (S) pulang karena dia (S) sakit. (Bahasa Indonesia)
25. Celine (S) hau In guI i (S) hua hi. (Hokkien)

Celine (S) menangis karena dia (S) bahagia. (Bahasa Indonesia)

26. Wa e a ku (S) ci cuI tua $\mathrm{k}^{\mathrm{h}} \mathrm{i}$ Boston koI sin ca me au. (Hokkien)

Paman saya (S) yang tinggal di Boston meninggal kemarin. (Bahasa Indonesia)

\section{Pola Gabungan Klausa Intransitif dan Transitif}

Seperti diketahui bahwa argumen yang muncul pada klausa intransitif adalah subjek (S) saja. Pada kalimat atau klausa transitif dimunculkan dua buah argumen inti, yaitu agen (A) dan pasien $(\mathrm{P})$. Oleh karena itu, gabungan klausa intransitif dengan klausa transitif akan memunculkan beberapa kemungkinan pola koreferensial, yaitu: $S$ pada kalimat intransitif diberlakukan sama dengan A dan P pada kalimat transitif. Sehinga dengan demikian, kemungkinan kekoreferensialan argumen yang didapat adalah berupa: $\mathrm{S}=\mathrm{A}, \mathrm{S}=\mathrm{P}$. Artinya subjek dari klausa intransitif pertama sama dengan atau koreferensial dengan agen atau pasien klausa kedua.

27. Olivia (S) bo sək lien suI bo $\emptyset(\mathrm{A}) \mathrm{p}^{\mathrm{h}} \Lambda \mathrm{k}$ ha le e kau liau. (Hokkien)

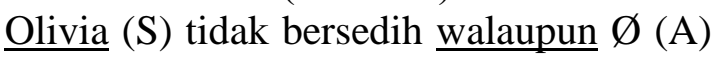
telah memukul anjing itu. (Bahasa Indonesia)

28. Na si wa $1 \wedge \eta(S)$ se uak hua hua hi hi, wa

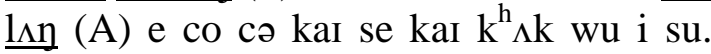
(Hokkien)

Jika kita (S) hidup dengan damai, maka kita (A) membuat dunia ini lebih berharga. (Bahasa Indonesia)

29. David (S) sək lien In guI Felix lao sə kua I (P) $\mathrm{t} \int^{\mathrm{h}} \mathrm{ut}$. (Hokkien)

David (S) bersedih karena Pak Felix mengusirnya $(\mathrm{P})$. (Bahasa Indonesia) 
30. I $1 \wedge$ 引 (S) hua hi e si $\varnothing(\mathrm{P})$ wu $\mathrm{k}^{\mathrm{h}} \wedge \mathrm{\jmath} \mathrm{k}^{\mathrm{h}}$ 。. (Hokkien)

Mereka (S) tetap bergembira saat $\varnothing(\mathrm{P})$ mendapat kesusahan. (Bahasa Indonesia)

\section{Pola Gabungan Klausa Transitif dan Intransitif}

Seperti diketahui bahwa argumen yang muncul pada klausa transitif adalah agen (A) dan pasien $(\mathrm{P})$ atau mungkin juga objek $(\mathrm{O})$. Sedangkan satu argumen inti berupa subjek (S) merupakan satu-satunya argumen yang muncul pada kalimat intransitif. Oleh karena itu, gabungan klausa transitif dengan klausa intransitif akan memunculkan beberapa kemungkinan pemolaan akan kedua klausa gabungan tersebut, yaitu $\mathrm{A}=\mathrm{S}$, dan $\mathrm{P}=\mathrm{S}$.

31. Listya (A) lim ko pi In gui $\varnothing$ (S) aI $\mathrm{k}^{\mathrm{h}} \mathrm{un}$. (Hokkien)

Listya (A) minum kopi karena $\varnothing$ (S) ngantuk. (Bahasa Indonesia)

32. Sur bo ie (P) miau ho tfra lon si, Ricky (S) tram kuat tuan. (Hokkien)

Walaupun kucingnya (P) mati tertabrak mobil, Ricky (S) tetap tabah. (Bahasa Indonesia)

33. Riani (A) ke $\mathrm{k}^{\mathrm{h}}$ 。 t fua na si $\varnothing(\mathrm{S})$ wu ey. (Hokkien)

$\underline{\text { Riani (A) mengoreksi kertas ujian ketika }}$ $\varnothing \quad(\mathrm{S})$ sedang senggang. (Bahasa Indonesia)

34. Linda (A) $\mathrm{t}^{\mathrm{h}} \Lambda \mathrm{k}$ ko $\mathrm{t}^{\mathrm{h}} \mathrm{ek}$ na si $\varnothing(\mathrm{S})$ wu $\mathrm{k}^{\mathrm{h}} \mathrm{i}$ t ${ }^{\mathrm{h}} \mathrm{u}$. (Hokkien)

Linda (A) membaca komik ketika $\varnothing(\mathrm{S})$ ada di rumah. (Bahasa Indonesia)

\section{Pola Gabungan Klausa Transitif dan Transitif}

Seperti diketahui bahwa argumen yang muncul pada klausa transitif adalah agen (A) dan pasien $(\mathrm{P})$. Oleh karena itu, gabungan klausa transitif dengan klausa transitif akan memunculkan 2 argumen agen dan pasien yang sama. Sehingga dengan demikian, kekoreferensialan argumen dapat terjadi dengan beberapa kemungkinan, yaitu, $\mathrm{A}=\mathrm{A}$ yang artinya adalah agen dari klausa transitif pertama sama dengan atau koreferensial dengan agen klausa kedua; $\mathrm{A}=\mathrm{P}$ artinya bahwa agen klausa pertama sama dengan atau koreferensial dengan pasien klausa kedua; dan $\mathrm{P}=\mathrm{A}$ artinya bahwa pasien klausa pertama sama dengan atau koreferensial dengan agen klausa kedua.

35. Annie (A) crak hın pau pau kau rau sın s $\Lambda$ n liau au $\underline{\text { i }}$ (A) co ho ie kıy. (Hokkien)

Annie (A) makan hamburger dengan lahap setelah dia (A) menyelesaikan tugasnya. (Bahasa Indonesia)

36. TaI sen wa $1 \wedge \eta$ (A) a bor gia con ci, wa $\underline{\ln }$ (A) be sar luan su. (Hokkien)

Sebelum kita (A) mengambil keputusan, kita (A) jangan bertindak gegabah. (Bahasa Indonesia)

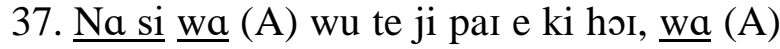
ar tur i ho ho. (Hokkien)

Seandainya saya (A) memiliki kesempatan kedua, saya (A) akan memperlakukannya dengan baik. (Bahasa Indonesia)

Di samping itu, kalimat subordinatif Bahasa Hokkien memiliki pula tipologi yang berbeda. Pola yang dimaksud adalah pola yang bersifat turunan, dimana terdapat lebih dari dua klausa dalam satu kalimat kompleks. Pola tersebut adalah sebagai berikut:

1. Pola $\mathrm{A} 1=\mathrm{S} 2=\mathrm{P} 3$

38. Wa $1 \Lambda \eta$ (A) a ne tur be $\mathrm{k}^{\mathrm{h}} \mathrm{i}$ liau au wa $1 \Lambda \eta$

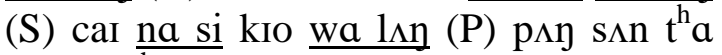
ma ca $\mathrm{k}^{\mathrm{h}} \mathrm{i}$ si lau cə ar lau a ma. (Hokkien) $\underline{\text { Kita }}$ (A) merasa sangat kasihan setelah kita (S) menyadari bahwa orang yang meminta bantuan kita $(\mathrm{P})$ tadi pagi adalah seorang nenek tua. (Bahasa Indonesia) 
2. Pola $\mathrm{A} 1=\mathrm{P} 2=\mathrm{A} 3$

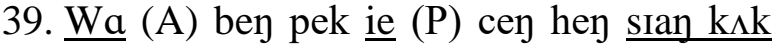
$\underline{\Lambda^{n} \text { cua }}$ i (A) bey pek wa (P). (Hokkien)

Saya (A) memahami keadaannya (P) sebagaimana dia (A) memahami diriku (P). (Bahasa Indonesia)

3. Pola $\mathrm{S} 1=\mathrm{A} 2=\mathrm{S} 3$

40. Na si i səy pek Jenny (A) tor ke mo, $\underline{\mathrm{i}}$ (A) en kar e nIa sit su na si $\underline{\mathrm{i}}(\mathrm{S})$ wu $\mathrm{k}^{\mathrm{h}} \mathrm{o}$ ley $\mathrm{k}^{\mathrm{h}} \Lambda \mathrm{k} \mathrm{k}^{\mathrm{h}} \Lambda \mathrm{j} \mathrm{k}^{\mathrm{h}} \curvearrowright$ koI tu sin e tai ci. (Hokkien) Apabila dokter mengharuskan Jenny (A) untuk menjalankan kemoterapi, dia (A) akan menerima fakta bahwa dia (S) harus lebih menderita jika memutuskan untuk menghadapi masalah baru. (Bahasa Indonesia)

4. Pola $\mathrm{S} 1=\mathrm{A} 2=\mathrm{S} 3$

41. E si Fenny (S) sək lien, $\underline{\mathrm{i}}$ (A) $\mathrm{t}^{\mathrm{h}} \mathrm{ra}$ ken kua $\Lambda^{\mathrm{n}} \mathrm{ni}$ i (S) e k $\mathrm{k}^{\mathrm{h}} \mathrm{k}$ son cə ba nra. (Hokkien)

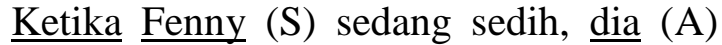
akan mendengarkan musik klasik sehingga dia (S) merasa lebih baik untuk beberapa saat. (Bahasa Indonesia)

5. Pola $\mathrm{S} 1=\mathrm{A} 2$ dan $\mathrm{S} 3=\mathrm{A} 4$

42. Leo (S) $\mathrm{k}^{\mathrm{h}}$ ua tiok bo a ne kıa kıa liau au $\varnothing$ (A) $\mathrm{t}^{\mathrm{h}}$ au $\mathrm{k}^{\mathrm{h}} \mathrm{ua}, \underline{\mathrm{n} \Lambda \mathrm{n} \mathrm{k} \wedge \mathrm{k}} \underline{\mathrm{i}}$ (S) e $\mathrm{t}$ far trau $\varnothing$ (A) co ha le e mui. (Hokkien)

$\underline{\text { Leo }}$ (S) tidak tampak gelisah setelah $\varnothing$ (A) mencontek, seolah-olah dia (S) mampu $\varnothing$ (A) mengerjakan soal-soal itu. (Bahasa Indonesia).

Dari pemeriksaan dan deskripsi singkat tentang data kalimat Bahasa Hokkien yang subordinatif, dapat disimpulkan hal-hal bahwa bahasa Hokkien memiliki semua tipologi bahasa yaitu akusatif, aktif, pasif, ergatif, dan antipasif. Alasan-alasan dan bukti gramatikal yang mendukung bahwa BM mempunyai konstruksi akusatif dan ergatif mengharuskan adanya tipologi bahasa "campur" atau "netral". Bahasa Hokkien adalah bahasa bertipologi netral pada tataran sintaksis. Perubahan morfologis verba suatu klausa dapat mempengaruhi argumen inti klausa yang lainnya. Dalam hal aliansi gramatikal kalimat subordinatif bahasa Hokkien dapat berupa pelesapan atau zero $(\varnothing)$, pronominal dan frasa nomina. Sistem koreferensial dasar kalimat bahasa Hokkien adalah berupa $\mathrm{S}=\mathrm{P}$ dimana $\mathrm{A}$ berbeda, dan $\mathrm{S}=\mathrm{A}$ dimana $\mathrm{P}$ berbeda. Ada beberapa pola turunan yang bergantung banyak penggabungan dan alternatif variasi penggabungan klausa intransitif dan transitif.

\section{DAFTAR PUSTAKA}

Arifin, Z. 2006. "Konstruksi Ergatif Baru dalam Bahasa Nusantara" Jurnal Kajian Linguistik dan Sastra. Volume 18. No. 34. 2006: 79-87.

Artawa, I Ketut. 2000. Alternasi Diatesis pada Beberapa Bahasa Nusantara dalam Kajian Serba Linguistik untuk Anton Moeliono Pereksa Bahasa. Jakarta: Unika Atmajaya dan PT. BPK Gunung Mulia.

2004. Balinese Language: A Typological Description. Denpasar: CV Bali Media Adhikarsa. 2005. Tipologi Bahasa dan Komunikasi Lintas Budaya (Orasi Ilmiah Pengukuhan sebagai Guru Besar Linguistik di Fakultas Sastra Universitas Udayana) Denpasar: Universitas Udayana.

Chaer, Abdul. 2003. Linguistik Umum. Jakarta: PT Rineka Cipta.

Comrie, Bernard. 1989. Language Universals and Linguistic Typology. Great Britain Billing \& Sons Ltd.

Dale, Amy Rose. 2016. Syntactic Ergativity: Analysis and Identification. California: Department of Linguistics, University of California, Berkeley. 
Dixon, R.M.W. 1979. Basic Linguistic Theory Volume I. Oxford: Oxford University Press.

1994. Ergativity. Cambridge: Cambridge University Press.

Handoko. 2015. "Analisis Kalimat Ergatif dalam Tajuk Berita Detik.com" Jurnal Arbitrer. Volume 2. Nomor 2 Oktober 2015: 135153.

Jufrizal. 2008. "Fenomena Tipologi Gramatikal Bahasa MinangKabau: Akusatif, Ergatif, atau Campur" Jurnal Linguistika. Volume 15. Nomor 28: 1-18.

Jufrizal, Rusdi dan Lely Refnita. 2009. "Struktur Informasi pada Klausa Bahasa MinangKabau: Sebuah Telaah Tipologi Gramatikal dan Struktur Informasi” Jurnal Lingua Didaktika. Volume 2. Edisi 4. Nomor 2. 2009: 58-69.

Manning D. C. 1991. Argument Structure and Grammatical Relations. California: CSLI Publications.

Perlmutter, David M. 1978. Impersonal Passives and The Unaccusatives Hypothesis. Chicago: University of Chicago Press. and Paul M. Postal. 1984. The I-advancement Exclusiveness Law. Chicago: University of Chicago Press.

Sawardi, FX. 2016. "Pergeseran Argumen dan Morfologi Verba Bahasa Jawa" Jurnal Internasional Prasasti III: Current Research in Linguistics. Nomor 2016: 288-292.

Sofyan, Akhmad. 2012. "Perilaku dan Makna Verba dalam Bahasa Madura" Jurnal Humaniora. Volume 24. Nomor 3 Oktober 2012: 333-344.

Sudaryanto. 2015. Metode dan Aneka Teknik Analisis Bahasa. Pengantar Penelitian Wahana Kebudayaan Secara Linguitis. Yogyakarta: Sanata Dharma University Press.

Verhaar, J. 2006. Dasar-Dasar Linguistik Umum. Yogyakarta: Gadjah Mada University.

Yayat, Sudaryat. 2002. Struktur Diatesis Kalimat dalam Bahasa Sunda. Bandung: Proyek Due-like UPI. 